\section{The process of}

news within the

theory of

information:

possible parallels

between the two

\section{concepts}

\section{ABSTRACT}

This article is about the process of news contextualized within Information Theory. Hence, it tries to define several concepts involved in the journalistic aspect and in Information Theory. It also covers the concepts of counter-information and disinformation.

\section{RESUMO}

Este artigo trata do processo das notícias contextualizadas com a Teoria da Informação. Define alguns conceitos envolvidos com 0 aspecto jornalístico e com a Teoria da Informação. Também discute os conceitos de contra-informação e desinfomação.

\section{KEY WORDS (PALAVRAS-CHAVE)}

- News (Notícias)

- Information Theory (Teoria da Informação)

- Disinformation (Desinformação)

\section{Roberto Porto Simões}

Ana Maria Córdova Wels

PUCRS/Brazil
IN 1948, THE North AMERICAN mathematician Claude Elwood Shannon presented the Mathematical Theory of Communication, coining the definition of Information to be "a reduction of uncertainty," (Shannon; Weaver, 1975: 53). This definition, reaffirmed by researchers from different areas of study, represented a break from previous studies, contributing to the evolution of new concepts.

Mostafa (1994: 22) states:

"Since 1950 (...) almost all the scientific disciplines made information a type of epistemological epicenter (...). Inform-ation became part of the definitions of many areas of knowledge as a type of unifying concept underlying the func-tioning of organized systems..."

From the etymological point of view, the word information derives from the Latin whose origin is included in the verb in-formo, which means give form to, form, portray, imagine, instruct (Azevedo, 1957:102), offering, in its root, possibilities of different interpretations and applications. The meaning of the word can be extended to "represent, present, create an idea or notion. In daily use, for the common man, this meaning is increased by the knowledge of a fact, a certainty of something"'(Simões, 1995: 150). Thus, information is referred to in the fields of study relative to Mathematics, Computer Science, Library Science, Administration, Politics, 
Education, Psych-ology, Communication and Natural Sciences, outlining an interdisciplinary and multidisciplinary view.

Nevertheless, it is in the area of social communication, specifically in journalistic endeavors, that one finds, as a final product, information presented in the form of news. From this concept, some parallels can be drawn between the two concepts, establishing interdisciplinary relationships in accordance with the combination of characteristics that define them and that make them legitimate. In order to do so, it is necessary to reflect on this possibility of interconnection based on a theoretical reading of some scientists in the areas of focus.

\section{The process of elaboration of the news and the informative function}

It is suitable, initially, to break down the process of elaborating and disseminating the news, observed and evaluated in light of the Theory of Information, so there is an understanding about the informative function that it must fulfill.

In this sense, it departs from the premise that the primary source for the creation of news is rooted in a real fact. It deals with a reality that will be retransmitted by the reporter, while he is the translator of a situation that is, in principle, of public interest. At this embryonic stage the process of gathering the news would begin, immediately considering some questions about its informative character. Lage (2000: 50) presents the news as "the relating of a series of facts by starting with the most important fact", emphasizing the idea of the narrative and its evolution at the same time that it focuses on "the understanding of the social and political role of the news", aligned to the two postulations: "that which emphasizes 'the right to information' and that which emphasizes 'the liberty to inform". Lage (2000) punctuates the idea of information related in journalistic material, while Marcondes Filho (1989: 13) defines the news as being its own "infor- mation transformed into a commodity with all its esthetic, emotional and sensational appeals; (...)". Pereira Jr. (2001: 62) refers to the news as "a form of seeing, perceiving and conceiving reality.(...)Information becomes more and more important in contemporaneity", and Wolf (1995: 170) makes mention of the idea that "knowledge of the world is acquired by the public through mass communication." In breaking down these definitions, it is possible initially to bring up for discussion the use of the word information at the center of the process of creating the news. According to the Theory of Information, a reporter works only with a group of data, since "the information gains its existence only from the point of view of the person that receives it and not from the point of view of the person who emits it." (Senra, 1994: 40). With a basis in this statement, it is worth saying that the information is, effectively, at the other point in the process where it must fulfill the proposal of acting as a "trigger for action"(Pignatari, 1982: 11), and must have a meaning that provokes an action on the part of the receiver, characterizing its utility.

Morin (1986:41) reaffirms that "information that resolves an uncertainty can eliminate a preoccupation and calm," and discusses the idea that other information, equally characterized by its function of utility and holding meaning for its recipient, can also provoke new uncertainties and promote new actions.

The process of creation of the news begins, then, from a fact that is the occurrence itself, that really happened, constituting, in short, "the raw material (the facts that occur in the world) of newsworthiness." (Wolf, 1995: 171). The fact will be recorded and fed by the media as an occurrence, as long as it fulfills the basic requirements that transform it into news. The news values "recommend the selection of a fact" (Wolf, 1995: 175) when there is a response to the questions that qualify these facts as interesting, significant and relevant.

Gomes's (2000: 80) reflections can be added to the extent that his approach 
to pragmatics - language and journalism - puts forward, among other proposals under discussion and dissemination, the idea that the microfacts, seen as the reference that sustains journalistic discourse, have as their only connection the support of the press or of the television program that presents them as pieces of news and as chosen events.

Morin (1986: 31) also refers to the media as creators of "the best system of information that can be conceived." For the author, it is a question of "a dense web that covers the surface of the globe, immediately picking up and transmitting the fact," designated as the embryo of the news.

As Wolf points out the factors that determine the newsworthiness of the facts, Lesly (1995: 105) presents, equally, a list of items that characterize an event worthy of being news, always emphasizing the importance of common interest in the reporting of the fact or notable situations, seen, then, as events. The question of interest in the news goes to the nature of the information, which will have significance and be absorbed as such when there is the intent to look for a message that meets a demand of the recipient. Among the items listed, Lesly (1995) cites, in first place, the new fact. Here another point of contact between news and information is established whereby the news includes something new to the receiver in its content.

Next, the author cites further the other factors that justify journalistic coverage for dissemination, those such as the unusual fact, situations related to famous people, conflicts, mysteries, confidential subjects, subjects that relate to the future, aside from miscellaney and others that are, necessarily, of public interest and reach all of society.

In the scope of novelty, Wiener (1970: 118) affirms that "the element of information, in order that it can contribute to the information of the community in general, has to be something substantially different from the previous inventory of the community's information," establishing a link of discourse between the "capacity for circulation" of the information and the restrictions imposed but not controlled and on the "rights of ownership" or copyright, fully inserted in the context of the communication. In this analysis, the subject is dealt with in the dimension of the community, as a contribution to the common knowledge, and supports the idea that information has to present new content to the recipient. Within the structure of news, developed from a new, truthful and useful datum, can be found characteristics that determine the informative function of its content.

It must be considered as well that, although news regarded as information must present new material to the recipient, the repetition of a subject already known, in the field of journalism, can contribute to reaffirming or contextualizing the content of the message. The Theory of Information calls this redundancy.

However much the origin of informative redundancy is linked to formulas of probability calculation, the approach considered here refers to repetition as intentional reinforcement, to better fix the message. In the specific case of journalistic text, even when there is the announcement of an unedited fact, it becomes necessary to contextualize the report, permitting the recipient to situate himself in relation to that topic, retrieving facts that are repeated with the objective of contributing to their correct reception, minimizing noises and preventing errors of interpretation. In this case, data are recovered that give support to the informative character of the news.

Marcondes Filho (1989: 13) complements his own definition of news, seen under a mercantilist lens, affirming that "information goes through a treatment that adapts it to the market norms of generalization, standardization, simplification and negation of subjectivism." In this sequence, it may be deduced that the news obeys some rules of formatting that permits its assimilation in accordance with the capacity for comprehension by the masses, utilizing its own codes 
considered from the basic elements that comprise a message, which are the data, until the language is refined journalistically, which requires professional authority to be elaborated. In this case, what is observed is that the codification of a message only has validity when it is under the control of the emitter and recipient, and in a contrary case there is no understanding, rejecting any possibility of exchange of information and impeding the establishment of the process of communication.

Thayer (1972: 209) comments on the nature of information, affirming that "potentially, everything is informative", in the meanwhile remembering that the message will only have an intended informative function if it is understandable by a specific receiver, emphasizing the necessity of understanding, that presupposes a common code. For Pignatari (1982: 39),

"the term code would have, then, a strictly technical use. The messages can be codified when they are already expressed by means of signs (letters, for example); then, a codification would be a transformation, generally uniform and reversible, through which messages can be converted from one set of signs to another."

Understood thus, the code is a convention of signs that give form to messages and, in this context, the information is presented as a result of the process of communication.

Lage (2000: 60) approaches Marcondes Filho in affirming that "the structure of the news is logical: the criterion of importance or interest involved in its production is ideological: it addresses psychological factors, market behavior, opportunity, etc.", endorsing the proposal that the news is worked and molded to answer a specific demand, classifying it, thus, as "an industrial product". In the same way, Lage acknowledges the "pragmatic restrictions" necessary in the production of the news, determined by way of the code's limitation, that requires the manipulation of the report, reducing the "amplitude of content to be communicated."

"Pragmatic restrictions" (Lage 2000) or the "simplification" of subject matter (Marcondes Filho, 1989) relate to synthesis, and according to the "negation of subjectivism" postulated by Lage, the discussion is channeled by the objectivity of the report. For Amaral (1996: 17), "objectivity is indicated as one of the principle virtues of journalistic material." It consists, in principle, in the way of seeing and translating a fact, observing it in an absolute way, without personal interference, abiding by "rigorous impartiality" and "thought without value judgment." This is a rational enough way of understanding objectivity. Meanwhile, as a subject discussed to exhaustion in the field of philosophy, Amaral (1996: 23) cites Japiassu in affirming that "...objectivity does not exist. What does exist is an objectivization, an approximated objectivity or an attempt to know reality in which it is what it is and not what we would like it to be."

At this point another area of discussion presents itself about the manner of making the news, that establishes itself precisely at the point in which the journalist finds himself confronted by a reality and has the mission to "inform about what happens in the community, in the country and in the world " (Amaral, 1996: 25). This degree of responsibility becomes amplified the more the media disseminates the fact.

Guareschi (2000: 28) observes:

"Communication creates reality, constructs reality. A thing comes to be, sociologically speaking, when it is broadcast (...) Those who withhold communication withhold, practically speaking, power, (...) exactly because of the fact that reality is constructed by communication".

Aside from Guareschi's proposal being linked to the discussion of ethics in communication, it is possible to advance our reflection on this subject, establishing 
another parallel of expressive importance to be delineated between the news and its informative function in respect to truth.

In this progression, we then must examine truth in the content of the news, so that the information will only be considered as such if it is a carrier of truth. On being misrepresented, the information looses its character and is presented as disinformation or contra-information, whose precedence is established in the error and in the lie. Durandin (1995: 31-33) talks about the subject, pointing out three basic correlating factors: 1 . reality properly stated; 2 . knowledge of this reality; 3 . the discourse. Between the two first steps the question of truth or error can be correlated, led by the primary reference, and, between the two following steps, a situation of truth or lie is established, which characterizes a conscious and intentional posture for discourse.

For Durandin, reality is the true object spoken about and for which there is the intent to know in order to retransmit. This perception of the object under examination exists in accordance with the representation more or less adequate that one makes of this reality. In this stage, the adequacy or not of the knowledge of the reality brings with it a condition of truth (adequacy) or error (inadequacy).

Translating this to the role fulfilled by the journalist confronting the fact, it can be said that the reading that he makes of the object is linked to technical aspects inherent in the profession.

The culture of the professional, the experience and the application of techniques of synthesis and objectivity should also be regarded, forcing the journalist to reject whatever preconceptions and idiosyncrasies that might possibly interfere in the primary contact of the creation of the news. The discourse, corresponding to the third step of the schematic presented by Durandin, establishes a "representation of the reality that is transmitted." When the discourse is adequate to the reality, a truthful discourse occurs, and when the contrary occurs, lies or a misleading discourse takes place. In this case, it must be considered that the data transmitted must be criticized as to their source and, only then committed as informative.

Morin (1986: 41) complements this:

\begin{abstract}
"An advance test does not exist to recognize good and bad information, truth and falsehood. To know how to read and discern, requires a difficult and random effort in deciphering, not the quality of verification similar to the machinery that detects false money.
\end{abstract}

Disinformation or contra-information, called pseudo-information by Morin (1986: 41) translates, then, conforming to how it was postulated, into the idea of falsehood, in opposition to the characteristic of truth that must be contained in the information. It must be emphasized, however, that the expression contra-information is terminology that runs through military language, defining a game of codes intentionally misrepresented by understanding among allies that offers false roads to confound adversaries. The author talks about this idea when he explains that the armed forces need to be fed information to trace uncertain or contingent action strategies, and that " military action looks to become informed about the preparations, means and movements of the enemy and needs to hide its own communications by means of a secret code." Referring to the informational war, he emphasizes:

"The value of the information, at the moment and place of a military offensive, is such that the secret services of the attacker strive to mislead, through false secret information, the secret service of the enemies, who fight to distinguish the 'true' information from the false".

Therefore it deals with purposeful contra-information, transmitted in the mili- 
tary field, with clear objectives of destabilizing the receiver.

On the trajectory of the path traveled by the news, the transmission channel of the message still has to be considered, it being the moving force in the process of communication. The printed and electronic means available require formatting techniques for the texts, images and speech, influencing the manner in which the facts will be gathered and retransmitted, in order to arrive at their destination with the most possible clarity. At this point, where there exists the necessity of reorganizing the data starting from a fact, the relating of the events passes through a new process of standardization and, in this process, a greater distancing occurs between reality and receiver, for the greater the number of links in a chain of communication the more natural are the modifications in the content of messages that may occur. Some aspects are reinforced, details can be forgotten or even rejected, while the importance of the facts can waver in the interests of addressing questions of ideological order to those of operational character.

Having understood the initial process of elaboration of the news and having in mind its ultimate function of informing, we arrive at the other extreme, where we find the receiver, to whom the material was directed. As in the initial elaboration of the subject matter, from the prior observation of reality made by a professional of the media, it is subject to a screening influenced by personal factors, in the same way that reception is harnessed to perception, generating attitudes, and determining opinions and behaviors. For Sternberg (2000: 147) perception consists of a collection of psychological processes through which people recognize, organize, synthesize and give meaning (in their minds) to the sensations received by the surrounding stimuli (the sensory organs).

Perception is directly linked to the individual psychological process, whose character is selective and subjective. From this process follows the generation of knowledge. Lazzarotto and Rossi (1991: 30) explain that "cognition is the 'act of knowing' and this begins with perception". Therefore, information is knowledge and cognition is the acquisition, organization and use of this knowledge. With this proposal, news is the source of knowledge and "intellectual materia-prima." (Klintoe, 1991: 55)

This set of internal and external variables, added to values, beliefs and emotions, gives substance to the attitudes that constitute, in themselves, "a predisposition to react to a stimulus (...) in a positive or negative manner." (Bowditch; Buono, 1992: 72). Therefore, attitudes predispose opinion and behavior. Da Viá (1983: 29) relates opinion to "the system of beliefs and ideologies of the individual" and cites G.W. Allport, presenting the idea that attitude linked to a "state of mental and nervous disposition, organized by experience, exerts direct and dynamic influence over the individual answers to all the objects and situations with which they deal." In this case, opinion is presented as one of the means of expression of this disposition, emphasized by its verbal and symbolic character, disclosed through various forms of language and types of communication. The attitude in its turn predisposes the individual to manifested behavior and to opinion. It is therefore attitude that leads to an intention of behavior that in turn will also influence subsequent attitudes corroborating the idea of circularity.

It is the final phase of the journey through the news that confirms its informative end. On finding himself with his public, the journalist, through his report, offers the public the product of a work that, in principle, has the initial intent to inform, transmitting new things, bringing knowledge, revealing truths, and also the belief that he is performing a useful service to his readers. At the other end, this same public has the use of knowledge divulged through the media and, on utilizing this content, corresponds to the expectations of its interlocutor. At this point, in which the news fulfills its 
function to "orient man and society in a real world"(Park, 1972: 183), it is the responsibility of each individual to access and look for knowledge in this wealth of journalistic material transmitted and retransmitted daily, conferring on the news the authenticity of its effectively informative function •

\section{References}

AMARAL, Luiz. A objetividade jornalística. Porto Alegre: SagraLuzzatto, 1996.

AZEVEDO, Fernando de. Pequeno dicionário latino-português. 8a.ed. São Paulo: Companhia Editora Nacional, 1957.

BOWDITCH, James L.; BUONO, Anthony F. Elementos do comportamento organizacional. São Paulo: Pioneira, 1992.

DA VIÁ, Sarah Chucid. Opinião pública - técnicas de formação e problemas de controle. São Paulo: Loyola, 1983.

EPSTEIN, Isaac. Teoria da informação. São Paulo: Ática, 1986.

DURANDIN, Guy. La información, la desinformación y la realidad. Barcelona: Ediciones Paidós, 1995.

GOMES, Mayra Rodríguez. Jornalismo e ciências da linguagem. São Paulo: Hacker Editores/Edusp, 2000.

GUARESCHI, Pedrinho A. Os construtores da informação: meios de comunicação, ideologia e ética. Petrópolis: Vozes, 2000.

KLINTOE, Kjeld. Interação entre empresas com necessidades de informação (=conhecimento) e a estrutura nacional de centros com provisão de conhecimento acumulado: referência especial à estrutura nacional de serviços de informação, documentação e biblioteca. Revista Ciência da Informação. Brasília, v. 20, n.1, p. 55-57, jan./jun. 1991.

LAGE, Nilson. Estrutura da notícia. 5aed. São Paulo: Ática, 2000.

LAZZAROTTO, Gisley Romanzini; ROSSI, Janete Schaeffer. "Comunicação, gestalt e behaviorismo". In: Comunicação e Controle Social. Petrópolis: Vozes, 1991.

LESLY, Philip. Os fundamentos de relações públicas e da comunicação. São Paulo: Pioneira, 1995. p.107.
LOJKINE, Jean. A revolução informacional. São Paulo: Cortez, 1995.

MARCONDES FILHO, Ciro. 0 capital da notícia. São Paulo: Ática, 1989.

Comunicação \& jornalismo: a saga dos cães perdidos. São Paulo: Hacker Editores, 2000.

MORIN, Edgar. Para sair do século XX. Rio de Janeiro: Nova Fronteira, 1986.

MOSTAFA, Solange Puntel. "As Ciências da Informação". Revista São Paulo em Perspectiva, São Paulo, v.8, n.4, p. 22-27, out.-dez. 1994.

PARK, Robert. "A notícia como forma de conhecimento". In: STEINBERG, Charles S. (org.). Meios de comunicação de massa. São Paulo: Cultrix, 1972.

PEREIRA Jr. Alfredo Eurico Vizeu. Decidindo o que é notícia: os bastidores do telejornalismo. 2aed. Porto Alegre: EDIPUCRS, 2001.

PIGNATARI, Décio. Informação linguagem comunicação. $11^{\mathrm{a}} \mathrm{ed}$. São Paulo: Cultrix, 1982.

SENRA, Nelson de Castro. "Por uma disseminação democrática de informações". Revista São Paulo em Perspectiva, São Paulo, v.8, n.4, p. 40-45, out.-dez. 1994.

SHANNON, Elwood; WEAVER, Warren. Teoria matemática da comunicação. Rio de Janeiro: Difel, 1975.

SIMÕES, Roberto Porto. Relações públicas: função política. São Paulo: Summus, 1995.

STERNBERG, Robert J. Psicologia cognitiva. Porto Alegre: Artmed, 2000.

THAYER, Lee. Princípios de comunicação administrativa. São Paulo: Atlas, 1972.

WIENER, Norbert. Cibernética e sociedade: 0 uso humano de seres humanos. São Paulo: Cultrix, 1970.

WOLF, Mauro. Teorias da comunicação. 4a.ed. Lisboa: Editorial Presença, 1995. 